\title{
The Ginger Prophecy; A Review of the Underexplored Genus, Hedychium against Cancer
}

\author{
P. VERMA AND R. KUNDU* \\ Centre of Advanced Study, Department of Botany, University of Calcutta, 35 Ballygunge Circular road, Kolkata-700 019, India
}

\section{Verma and Kundu: Anticancer Potential of Gingers}

\begin{abstract}
Cancer, the seventh most fatal disease in the world, poses a long struggle to combat this deadly disease. Economically and pharmacologically important members of Zingiberaceae plant family have helped to eradicate a number of ailments worldwide. This review highlights gingers and their wide spectrum of medicinal values focusing on their role as anticancer agents with facts and data obtained from literature review performed using PubMed, PMC, ScienceDirect, Google Scholar in a systematic way. Among the many genera underlined in this review, several species of Hedychium have emerged as potential cancer treatments with remarkable activity against different forms of tumour. However this genus is not much explored to unravel its value to medical research. Several species have been found to have cytotoxic, antiinflammatory, antioxidant and antitumour activities but not many attempts made to establish the plant principles as anticancer agents.
\end{abstract}

Key words: Natural products, cancer, chemoprevention, Zingiberaceae, Hedychium

In the traditional medicine, plants have been used for centuries to treat various diseases ${ }^{[1]}$. Natural products from plants are also used in several therapeutic formulations ${ }^{[2]}$. These compounds belong to different chemical classes (alkaloids, phenolics, flavonoids, terpenoids) and have diverse complex chemical structures. Natural products contributed many drugs that are currently available in the market for the treatment of a number of diseases ${ }^{[3]}$.

Cancer is a disease occurring at an alarming rate in the last few decades throughout the world. It is a multifactorial disease, which results in uncontrolled growth of cells and their invasion leads to the formation of tumour in the human body. There has been a steep rise in the number of cases where patients have been reported to be suffering from various kinds of cancers $^{[4]}$. This may be attributed to the change in food habits, excessive consumption of tobacco and alcohol, chronic infections, exposure to harmful radiations and chemicals, industry waste/fumes or more widely due to change in lifestyle and environmental pollution ${ }^{[5]}$. Cancer is among the leading causes of death worldwide. With figures obtained from GLOBOCAN 2018, there has been 18.1 million cases of cancer incidence and 9.6 million cases of human mortality occurred due to cancers reported worldwide ${ }^{[6]}$. The mortality rate of

*Address for correspondence

E-mail: kundu_rita@yahoo.co.in

January-February 2020 cancer patients is enormous. The situation is much critical in economically challenged countries like Africa due to the lack of education, infrastructure, medicinal amenities, diagnostic services and high cost of the treatments ${ }^{[7]}$.

Natural plant products are under exploration to discover new chemical entities as anticancer agents which is also one of the breeding areas of research in the scientific field. Natural products are inexpensive, easily available, mostly beneficial to human health, which makes their use more popular among the public generally but also easily accessible for research and at most times prove to be better forms of alternative medicine.

Among the natural plant resources, Angiosperms are a huge reservoir of products with medicinal values ${ }^{[8]}$. One such plant family with significant pharmacological gravity is the family of gingers, the Zingiberaceae, which consisted of annual or perennial herbs with creeping horizontal or tuberous rhizomes ${ }^{[9]}$. The

This is an open access article distributed under the terms of the Creative Commons Attribution-NonCommercial-ShareAlike 3.0 License, which allows others to remix, tweak, and build upon the work non-commercially, as long as the author is credited and the new creations are licensed under the identical terms

Accepted 06 November 2019 Revised 13 August 2019

Received 18 February 2019 Indian J Pharm Sci 2019;82(1):11-20 
family comprises of 50 genera and about 1500 species distributed throughout tropical Asia ${ }^{[10]}$. The gingers mostly need shady, humid environments with timely water showers for proper growth.

The plant family Zingiberaceae is a paramount natural resource that provides many useful products for food, spices, medicines, dyes, perfume and aesthetics ${ }^{[11]}$. It constitutes a family of rhizomatous, aromatic medicinal plants characterised by the presence of volatile oils and oleoresins ${ }^{[12]}$. The plants are widely distributed mostly in tropical and subtropical regions of Asia especially Thailand, Indonesia, Malaysia, India as well as in America and Australia ${ }^{[13]}$. Curcuma, Kaempferia, Hedychium, Amomum, Zingiber, Alpinia, Elettaria and Costus are some of the economically important genera of Zingiberaceae. These are all well known for traditional medicinal uses ${ }^{[12]}$.

The rhizomes of the plants of this family are predominantly aromatic, analeptic and stimulant. They are rich sources of essential oils that consist of numerous complex terpenoid mixtures. Many terpenoid compounds with varied physiological activities, antimicrobial, antiarthritic, antioxidant, anticancer, antiinflammatory, antidiabetic, antiHIV and neuroprotectives have been identified in the essential oils of ginger plants ${ }^{[14]}$. Considering the wide range of pharmacological activities possessed by the various genera of gingers, which also makes them economically cardinal, their uses have been compiled and represented in Table $1^{[15-44]}$.

Apart from the broad range of pharmacological activities possessed by the different ginger genera, many members are reported to have important anticancer activities $^{[45]}$. Gingers besides being commonly used as spices and flavouring agents by local people worldwide, they are an essential and frequently available source of antiinflammatory constituents, which can be utilised to combat various forms of cancer or so as to prevent its occurrence $^{[46,47]}$. These gingers could play an essential role in developing anticancer drugs. The attempt of making use of edible ginger forms to prevent or treat cancer accounts to its contribution to chemoprevention. Table $2^{[48-72]}$ is a compilation of common gingers and their reported anticancer activity. The various disadvantages of chemotherapy, which involves treatment of cancers with standard chemical therapeutic drugs include several side effects like nausea, loss of appetite, hair loss, anaemia and vomiting ${ }^{[73]}$. Other than these, treatment at high cost, longer time span and the pain the patient suffers post treatment are also a matter of concern. Chemotherapy is usually clubbed with surgery and radiation therapy. In addition to that, targeted therapy ${ }^{[74]}$, neoadjuvant therapy ${ }^{[75]}$, immunotherapy ${ }^{[76]}$, treatment with herbal medicines and natural sources

\section{TABLE 1: GINGERS WITH PHARMACOLOGICAL AND ECONOMICAL IMPORTANCE ${ }^{[15-44]}$}

\begin{tabular}{|c|c|c|}
\hline Botanical name (common name) & Parts used & Bioactivity \\
\hline $\begin{array}{l}\text { Alpinia galanga (Linn.) Willd. (greater galangal/ } \\
\text { blue ginger) }\end{array}$ & Rhizome & $\begin{array}{l}\text { Antiinflammatory }{ }^{[15]} \text {, antiallergic }{ }^{[16]} \text {, gastroprotective }{ }^{[17]} \text {, } \\
\text { cytotoxic }^{[18]} \text {, neuroprotective effect }\end{array}$ \\
\hline Alpinia nigra BURTT. & $\begin{array}{l}\text { Tender shoot } \\
\text { and rhizome }\end{array}$ & Fluckicidal $^{[20]}$, antimycobacterial[ ${ }^{[21]}$ \\
\hline Amomum aromaticum Roxb. (Bengal cardamom) & Seeds & Antimycobacterial ${ }^{[21]}$, antileishmanial ${ }^{[22]}$ \\
\hline Amomum subulatum Roxb. (black cardamom) & Pods & $\begin{array}{c}\text { Treatment of cardiovascular diseases }{ }^{[23]}, \\
\text { hepatoprotective }\end{array}$ \\
\hline Curcuma amada Roxb.(mango ginger) & Rhizome & $\begin{array}{c}\text { Cholesterol lowering activity }{ }^{[25]} \text {, antioxidant and } \\
\text { antibacterial[26] }, \text { antitubercular }{ }^{[27]}\end{array}$ \\
\hline Curcuma longa L. (turmeric) & Rhizome & $\begin{array}{l}\text { Antiinflammatory }{ }^{[28]} \text {, antioxidant }{ }^{[29]} \text {, antifungal }{ }^{[30]}, \\
\text { antitumour } \\
\text { treatment of cardiovascular diseases }\end{array}$ \\
\hline Curcuma zedoaria Rosc. (Zedoary) & Rhizome & $\begin{array}{c}\text { Antiinflammatory }{ }^{[34]} \text {, anticancer activity }{ }^{[35]}, \\
\text { antiangiogenic effect }\end{array}$ \\
\hline $\begin{array}{l}\text { Elettaria cardamomum (Green/true } \\
\text { cardamomum) }\end{array}$ & $\begin{array}{l}\text { Seeds and } \\
\text { pods }\end{array}$ & Antispasmodic ${ }^{[36]}$ \\
\hline $\begin{array}{l}\text { Kaempferia galanga L. (sand ginger/resurrection } \\
\text { lily) }\end{array}$ & $\begin{array}{l}\text { Leaves and } \\
\text { rhizomes }\end{array}$ & Vasorelaxant ${ }^{[37]}$, larvicidal activity ${ }^{[38]}$ \\
\hline Kaempferia rotunda L.(Bhumichampa) & $\begin{array}{l}\text { Leaves and } \\
\text { rhizomes }\end{array}$ & Insecticidal ${ }^{[39]}$ \\
\hline Zingiber officinale Rosc. (garden ginger) & Rhizome & $\begin{array}{l}\text { Antioxidant }{ }^{[40]} \text {, treatment of cardiovascular diseases } \\
\text { antiobesity }{ }^{[23]} \text {, anticancer } \\
{ }^{[42]}, \text { antinausea/vomiting }\end{array}$ \\
\hline Zingiber zerumbet Smith. (bitter ginger) & Rhizome & $\begin{array}{l}\text { Anticancer, antiinflammatory, antiHIV, antiAlzheimer's } \\
\text { disease, multipotential bioactivities }{ }^{[44]} \\
\text { antileishmanial }\end{array}$ \\
\hline
\end{tabular}


www.ijpsonline.com

TABLE 2: COMMON GINGERS AND THEIR ANTICANCER ROLES ${ }^{[48-72]}$

\begin{tabular}{|c|c|c|}
\hline Anticancer agent & Plant source & Cancer cell line(s) tested/cancer type \\
\hline $\begin{array}{l}\text { Acetoxyeugenol acetate, acetoxychavicol } \\
\text { acetate, isocoronarin D, caryolane }\end{array}$ & Alpinia galanga (rhizome) & HeLa, A549, HepG2, SMMC-7721 ${ }^{[48]}$ \\
\hline Galangin & Alpinia officinarum (rhizome) & $B 16[49]$ \\
\hline Yakuchinones A and B & Alpinia oxyphylla & $\begin{array}{l}\text { HL-60 }{ }^{[50]} \text { HepG2 }{ }^{[51]}, \text { HepG2, BEL-7402, } \\
\text { SMMC-7721, Hep3B }{ }^{[52]}\end{array}$ \\
\hline Volatile oils & Alpinia officinarum & A549[53] \\
\hline Caffeic acid, apigenin, curcumin, pinnocambrin & Alpinia pricei (rhizome) & $\mathrm{CH} 27, \mathrm{HL} 60, \mathrm{~A} 549^{[54]}$ \\
\hline Curcumin & Curcuma sp (rhizome) & $\begin{array}{c}\text { Prostate cancer, MCF 7, MDA MB 231, } \\
\text { BT474, Pancreatic, Colorectal, Daltons } \\
\text { lymphoma cells }\end{array}$ \\
\hline Isocurcumenol & Curcuma zedoaria (rhizome) & $\mathrm{A} 549, \mathrm{~KB}, \mathrm{~K} 562^{[57]}$ \\
\hline Curcumin & Curcuma zedoaria (rhizome) & CORL 23, PC $3^{[58]}$ \\
\hline- & Curcuma amada (rhizome) & MCF 7, HBL 100, MDA MB 231 ${ }^{[59]}$ \\
\hline Curcumol & Curcuma kwangsiensis & LoVa, SW480[60] \\
\hline Curcumin & Curcuma longa & A549 ${ }^{[61]}, \mathrm{PC}^{[62]}$, melanoma ${ }^{[63]}$ \\
\hline A-zingiberene, gingerol & Zingiber officinale (rhizome) & $\begin{array}{c}\text { HeLa, SiHa }{ }^{[64]}, \text { HCT116, SW480, LoVo } \\
\text { MDA-MB-231 }\end{array}$ \\
\hline Zerumbone & Zingiber zerumbet (rhizome) & $\mathrm{CHL}-1^{[67]}$ \\
\hline Extract & Etlingera elatior & $B 16^{[68]}$ \\
\hline $\begin{array}{l}\text { Protocatechuic acids, syringic acid, ferulic acid, } \\
\text { rutin, apigenin, kaempferol }\end{array}$ & $\begin{array}{l}\text { Roscoea purpurea } \\
\text { (rhizome) }\end{array}$ & SiHa, A 549, CHOK 1,C-6[69] \\
\hline Extract & Kaempferia parviflora & SKOV $3^{[70]}$ \\
\hline Panduratin A & $\begin{array}{c}\text { Kaempferia pandurata } \\
\text { (rhizome) }\end{array}$ & HepG2[71] \\
\hline Panduratin A & $\begin{array}{l}\text { Boesenbergia pandurata } \\
\text { (rhizome) }\end{array}$ & MCF 7, HT 29[72] \\
\hline
\end{tabular}

(as complementary and alternative medicines) ${ }^{[77]}$ are also used for therapeutic purpose.

In the present review, the therapeutic activity of Hedychium is highlighted with latest studies performed in past $10 \mathrm{y}$ and related information from past two decades mostly. Hedychium is an important member of plant family Zingiberaceae, not explored adequately for its anticancer activity till date.

\section{An introduction to Hedychium:}

Among the economically known genera one such important genus is Hedychium, which consists of about 80 species and is among the well-known genera of Zingiberaceae because of its striking foliage, diversified flamboyant flowers and sweet aroma ${ }^{[78]}$. Hedychium genus is spread throughout tropical and temperate Asia (China, Indian subcontinent and Southeast Asia) and Madagascar ${ }^{[79-81]}$. The genus Hedychium was established by Koenig in 1783, based on the type species H. coronarium Koenig. Many species of Hedychium possess some pharmaceutical importance ${ }^{[82]}$. This makes the genus economically popular. Hedychium emerge during the monsoon season and hence need to be kept warm, wet and well-nourished in the summers. The plant demands well drained soil which can retain optimum moisture $^{[83]}$.
This review highlights the therapeutic uses of a few popular and important genera of ginger family with emphasis on Hedychium species and the active antitumour principles, which have been analysed and are under local use. It was observed that not many species of the genus have been examined for cytotoxic or antitumour potential. Out of the ones studied, only a few have been analysed in details but still not propelled towards development as a drug for chemoprevention. Rest of the species have only been studied at elementary level. It can be concluded conclusively that Hedychium is an underexplored genus with ample pharmaceutical values not discovered or utilized to its complete potential.

\section{General medicinal values and antitumour activity of selected species of Hedychium:}

Hedychium coronarium J. Koenig is an extremely popular medicinal plant. The plant is hardy in nature growing at high altitudes in the foothills of Himalayas extending from east Nepal through India to China. An essential oil obtained from the rhizome has anthelmintic, carminative and antibiotic properties. The common names of the plant append white ginger lily, dolan chapa (Bengali) and Gulbakawali (Hindi) ${ }^{[84]}$. The plant possesses antihypertensive and diuretic properties ${ }^{[85]}$. 
Different extracts of the plant exhibit antiinflammatory activity by inhibiting 5-lipoxygenase ${ }^{[86]}$, possesses analgesic effects ${ }^{[87]}$ and leishmanicidal activities ${ }^{[88]}$. Aqueous extract of the plant was found to lower glycaemia in diabetic rodent models ${ }^{[89]}$. Suresh et al. ${ }^{[90]}$ showed the presence of two new labdane diterpenes along with coronarin $\mathrm{D}$ and $\mathrm{C}$, coronarin $\mathrm{D}$ methyl ether, cryptomeridiol, hedychenone, pacovatinin, 6-oxo-7,11,13-labdatriene-16,15-olide, 4-hydroxy-3methoxy cinnamaldehyde and 4-hydroxy-3-methoxy ethyl cinnamate from the plant with cytotoxic effects on A-549 (lung cancer), SK-N-SH (human neuroblastoma), MCF-7 (breast cancer) and HeLa (cervical cancer) cell lines. Similar work carried out by Zhan and colleagues showed positive cytotoxic and antiinflammatory effects of common isolates upon B16, HT-29, HeLa and HepG2 cell lines ${ }^{[91]}$. During inflammatory reciprocation, activation of the nuclear transcription factor-kB (NF-kB) is an essential step ${ }^{[92]}$. The event of activation of NF-kB transcription factor is involved in process of inflammation, cell multiplication and oncogenic operations ${ }^{[33]}$.

Popular for its antiinflammatory activity, presence of 4 isolates in the plant namely 7- $\beta$-hydroxycalcaratarin A, calcaratarin A, coronarin A and E-labda-(17), 12-diene-15,16-dial were found in the plant possessing antiinflammatory potential which supports the traditional use of the plant in the prevention or treatment of various inflammatory diseases ${ }^{[94]}$. coronarin D has been shown to constrain the activation of the NF-kB pathway induced by different carcinogens and pro-inflammatory molecules and also debilitate the expression of constitutive NF-kB ${ }^{[95]}$. Chen and co-workers ${ }^{[96]}$ reported that coronarin $\mathrm{D}$ induced ROS-mediated death in human nasopharyngeal cells by activating JNK along with inhibition of p38 MAPK whereas Giron and co-workers ${ }^{[95]}$ found that coronarin D inhibits NF-kB also by down regulating IKK activation.

Panigrahy and co-workers ${ }^{[97]}$ showed that different extracts from the rhizome of the plant were found to be rich in total phenolic content and antioxidant capacity. This establishes H. coronarium as a potential resource of bioactive molecules which may be utilized as a remedy to treat diseases which result due to oxidative stress.

In an oncology based study it was seen that the methanol extracts of $H$. coronarium exhibited anticancer activity and acts as a potent growth suppressive agent against human breast cancer MCF-7 cells in vitro ${ }^{[98]}$. A very recent study reported about the ethanol extracts of the plant exhibiting considerable antiproliferative effect upon HeLa cervical cancer cells. The extract treatment led to upregulation of Bax and conversely acting on $\mathrm{Bcl} 2$. It also led to arrest of the cell cycle at G1 phase with increased levels of p21 and p53 with downrigger of CDK4, 6 and cycD1. The extracts could activate the caspase signalling cascade with enhanced roles of caspase 9,8 and 3. It successfully downregulated MMP2 and 9 and thus inhibited the migratory capacity of HeLa cells ${ }^{[99]}$.

H. spicatum (Ham-ex-Smith) is a perpetual rhizomatous herbaceous plant. Commonly called Shati, Ban Haldi and Kapur Kachri (Hindi), the plant is distributed in subtropical Himalayan range including Uttarakhand, Assam, Arunachal Pradesh at fairly high altitudes and extreme cold temperatures ${ }^{[100]}$. Pharmacologically, $H$. spicatum is widely used to treat several diseases. Sravani and Paarakh ${ }^{[101]}$ presented a detailed overview on the plant where they mentioned about the plant to be possessing antiinflammatory, analgesic, antifungal, hypotensive, antipyretic properties and it also helps in indigestion, bronchitis and treatment of eye diseases. The rhizome also exhibits spasmolytic, vasodilatory, hypoglycaemic, hypotensive, antimicrobial and antioxidant activities ${ }^{[102]}$. Tandon et al. defined the analgesic potential of the plant ${ }^{[103]}$. Decoction of the plant is used to treat cold and cough in Nepal ${ }^{[104]}$.

The anticancer potentials of $H$. spicatum have been studied in the past few years. Results of the MTT assay carried out with the methanol extracts of $H$. spicatum upon HeLa cervical cancer cells presented an $\mathrm{IC}_{50}$ value of $48.77 \mathrm{ppm}$ hinting at the plant to be a promising anticancer drug aspirant ${ }^{[105]}$. Reddy et al. ${ }^{[106]}$ isolated two new labdane diterpenes from the plant. Compound 1 had significant cytotoxic role upon Colo 205, CHO, MCF-7 and A459 cell lines. Compound 2 showed good killing effect upon the $\mathrm{CHO}$ cells. Bhatt and co-workers ${ }^{[107]}$ concluded that the phenolic tocopherol content in $H$. spicatum was significantly high in one year old planted rhizome. Tocopherol is a known antioxidant compound which possesses biological activities such as immune stimulation and alteration of metabolic activation of proto-oncogenes ${ }^{[108]}$ and hence assists in cancer prevention.

H. thyrsiforme is synonymously called Gandasulium thyrsiforme (Sm.) Kuntze. The plant is localised in India, Nepal, Bangladesh and Vietnam ${ }^{[109]}$. The plant has not been evaluated for pharmacological values other than an account of its antioxidant 
and anticancer activity reported by Jasril et al. ${ }^{[110]}$. The team analysed n-hexane and dichloromethane extracts from the rhizome of the plant. They isolated 5-kaempferol type flavonoids, 3,7,4'-trimethoxy5-hydroxyflavone, ermanin, 3,7,4'-trimethoxy5,7dihydroxyflavone, 3,5,7,4'-tetramethoxyflavone and 7,4'-didimethoxy-3,5-dihydroxyflavone. Compounds ermanin, 3,7,4'-trimethoxy5,7-dihydroxyflavone and 7,4'-didimethoxy-3,5-dihydroxyflavone depicted fine antioxidant property. Antitumour capability of these compounds was assessed to evaluate their inhibitory role towards activation of EBV in Raji cells. All 5 compounds showed sturdy inhibition at concentrations as low as $10 \mu \mathrm{g} / \mathrm{ml}$. This study attempted to corelate the antioxidant and antitumour role of the plant rich in flavonoids as latter are well known antioxidants ${ }^{[111]}$. They also inculcate antiinflammatory, antiviral, antiangiogenic, anticarcinogenic properties ${ }^{[112]}$. With only a single evidence about the antitumour potential of the plant $H$. thyrsiforme, the plant appears to be an important natural provenance for anticancer remedies which has not faced much exploitation yet.

H. ellipticum Buch. is locally called Pankhaful (Hindi). The plant is localised in Nepal, Bhutan, Thailand and Vietnam $^{[113]}$. The plant holds several pharmacological values. The tuber of the plant is used in the treatment of liver disorders and is contained with antiinflammatory activity $^{[14]}$. The n-hexane and dichloromethane extracts of the rhizome of the plant was evaluated with good antituberculosis activity against the

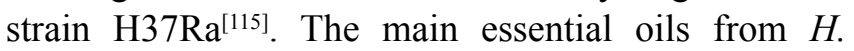
ellipticum studied using GC-FID and GC-MS by Thanh et al. were $(11 \%) \beta$-pinene, $(18.3 \%) \alpha$-pinene and (40.8\%) 1,8-cineole in the roots of the plant. The leaves contained (9.2\%) bornyl acetate, (11.8\%) $\beta$-pinene and $(15.9 \%)$ nerolidol ${ }^{[16]}$. Cineole or eucalyptol is found to supress expression of COX-2 through UVB-induced carcinogenesis in $\mathrm{HaCaT}$ cells and also inhibit generation of prostaglandin E2 in the cells ${ }^{[117]}$. Pinene also, is found to reduce the growth of tumour in mice ${ }^{[118]}$. Nerolidol is reported to possess anticancer activity upon $\mathrm{HeLa}$ cancer cells with an $\mathrm{IC}_{50}$ as low as $1.5 \mu \mathrm{M}^{[119]}$. Songsri and Nuntawong ${ }^{[115]}$ reported isolation of 10 labdane diterpenoids from the rhizomes of the plant, among which, coronarin E, coronarin D, villosin, 15-methoxylabda-8(17),11,13-trien-15, 16-olide and 16-hydroxylabda-8(17),1113rien-15, 16-olide were found to possess good antitumour activity. Villosin, 15-methoxylabda-8(17),11,13-trien-15, 16-olide and 16-hydroxylabda-8(17),11,13-trien-15, 16-olide were also tested upon KB (oral cavity), MCF-7 (breast) and A-549 (lung) cancer cell lines and were evaluated to be powered with considerable cytotoxicity. According to previous and latest reports, coronarin $\mathrm{E}$ is shown to have positive cytotoxic effect on HL-60 (leukemic), THP-1 (leukemic), A-375 (melanoma) and A549 (lung) cancer cell lines ${ }^{[106]}$. Similarly, coronarin D was found to have induced apoptosis and G2/M cell cycle arrest in human oral cancer cell lines SAS and SCC-9 ${ }^{[120]}$.

H. yunnanense are perennial herbaceous plants which have rotund fleshy rhizomes. The plant is native to Vietnam, south-east and south-central China. It grows with a single inflorescence ${ }^{[121]}$. Qing et al. ${ }^{[122]}$ prepared crude extracts of $H$. yunnanense which were tested in vivo for assessing the anticancer potential of yunnancoronarin $\mathrm{A}$ and hedychenone. It was found that the compounds showed significantly inhibitory effects on H22 tumour in ICR mice. Yunnancoronarin A displayed the strongest suppression, with the inhibitory ratio of $54.27 \%$. Yunnancoronarin $\mathrm{C}$ also showed durable anticancer effect on human breast cancer cell line MDA-MB-231 in vitro. Another work done by $\mathrm{Li}$ and colleagues ${ }^{[123]}$ reported the use of rhizomes of H. yunnanense collected from Yunnan. The ethanol extracts were subjected to column chromatography, which eluted a novel labdane diterpene, hedychenoid $\mathrm{B}$ and two other known compounds hedychenone and villosin, all of which exerted cytotoxic effects against SGC-7901 (gastric cancer) cell line with extremely low $\mathrm{IC}_{50}$ concentrations. The latter two also showed cytotoxicity against $\mathrm{HeLa}$ with considerably low $\mathrm{IC}_{50}$ values. Evidently, the plant contained compounds with remarkable therapeutic potential but unfortunately these species were not explored to realise their medicinal potential. It can be concluded that this ginger is an important natural resource as an anticancer remedy which needs exposure by the research arena for development of better drugs against various forms of cancer.

H. forrestii is a hardy and vigorous plant with white flowers and delightful sweet fragrance. It is commonly known as Forest's hardy ginger lily. General medicinal values have not been well explored. Zhao et al. ${ }^{[24]}$ isolated two new labdane diterpenoids, hedyforrestin $\mathrm{D}$ and 15-ethoxy-hedyforrestin $\mathrm{D}$ along with three other known compounds, yunnancoronarin A, yunnancoronarin $\mathrm{B}$ and yunnancoronarin $\mathrm{C}$ with the help of column chromatography from the ethanol extract partitioned against ethyl acetate to give a brown oil. The cytotoxic activity of these 5 compounds were 
evaluated against A-549 (lung) and K562 (leukaemia) cell lines. Yunnancoronarin A and B were most active $(\mathrm{A}>\mathrm{B})$ against lung adenocarcinoma and the activity of these compounds against K562 was in the order of yunnancoronarin $\mathrm{B}>$ yunnancoronarin C>yunnancoronarin $\quad \mathrm{D}>15$-ethoxy-hedyforrestin $\quad \mathrm{D}>$ hedyforrestin D. In reality, not much work was reported on this ginger variety thus it can be concluded that the plant possessed ample potential to be developed as an anticancer agent which requires further studies.

$H$. gardenerianum ex ker-Gawl is native to the Himalayas. The essential oil of the plant exhibited antithrombin and antibacterial activity ${ }^{[125]}$. Arruda et al. ${ }^{[126]}$ studied the essential oils of $H$. gardnerianum, which exhibited antiacetylcholinesterase and antioxidant activity making the plant potentially be useful as an adjuvant in treatment of Alzheimer's disease. Kumrit et al. ${ }^{[127]}$ reported isolation of 7 labdane diterpenes from this plant, which showed cytotoxic activity. They isolated coronarin E, coronarin A, yunnancoronarin A, yunnancoronarin B, hedyforrestin B, villosin and hedyforrestin $\mathrm{C}$ from the rhizome of this plant and tested the cytotoxic activity in vitro on lung cancer (NCI-H187) and non-cancerous Vero cells. Villosin displayed most promising cytotoxic potential with an $\mathrm{IC}_{50}$ of $0.40 \mu \mathrm{M}$ against the lung cancer cells, while noncytotoxic even at higher concentrations on Vero cells. These results indicated that the lactone ring was essential for considerable cytotoxic activity. This plant species is also unexplored considering the pharmacological potential the plant holds.

The plant family of Gingers consisted of economically as well as pharmacologically important genera wherein the plants exhibit a wide spectrum of medicinal properties that include antimicrobial, antioxidant and antiinflammatory activities. These gingers are maximally found in the Asian lands and have faced much exploitation in lieu of development of natural drugs against several diseases. Hedychium was initially explored and its chemical constituents and pharmaceutical importance has also been depicted in various reports. This review has primarily focused on the antitumour potential of various species of Hedychium. $H$. coronarium is a very well-studied member with finely-established anticancer and antiinflammatory role of its active principles on various cancer forms both in vitro and in vivo. Whereas other members such as $H$. thyrsiforme, $H$. gardnerianum, $H$. yunnanense and H. forrestii are the least explored forms in field of cancer biology and thus they are of immense value for research to understand their antitumour potential. A common notable finding in this review is the absence of reports on in vivo activity and hence it is not possible to establish chemotherapeutic value of the phytoconstituents of this genus. Species other than $H$. coronarium and $H$. spicatum have not garnered much attention may be due to relative unavailability and medicinally unknown in countries other than south-east Asian countries.

The plant family of Gingers or Zingiberaceae has ample medicinal properties including anticancer capacity. Hedychium holds potential with its unexplored members which could make a difference in development of better chemopreventive drugs in future. Hedychium is a treasure plant with prepatent in the fight against prevention and treatment of cancers worldwide. $H$. coronarium is the only well studied species in the area of cancer research, while the others are under explored to identify the anticancer potential that they possess. Gain of popularity by different plant species of the genus and knowledge about their usage would provide better treatment options for cancer in near future.

\section{Acknowledgements:}

The authors recognise the contribution of UGC CAS Phase VII and UGC-UPE II for the financial and infrastructural assistance provided during the present review work. PV acknowledges UGC for the fellowship.

\section{REFERENCES}

1. Dias DA, Urban S, Roessner U. A Historical Overview of Natural Products in Drug Discovery. Metabolites 2012;2(2):303-36.

2. Katiyar C, Gupta A, Kanjilal S, Katiyar S. Drug discovery from plant sources: An integrated approach. Ayu 2012;33(1):10-19.

3. Yuan H, Ma Q, Ye L, Piao G. The Traditional Medicine and Modern Medicine from Natural Products. Molecules 2016;21(5):E559.

4. Rajpal S, Kumar A, Joe W. Economic burden of cancer in India: Evidence from cross-sectional nationally representative household survey, 2014. PLoS One 2018;13(2):e0193320.

5. Anand P, Kunnumakara AB, Sundaram C, Harikumar KB, Tharakan ST, Lai OS, et al. Cancer is a preventable disease that requires major lifestyle changes. Pharm Res 2008;25(9):2097116.

6. Ferlay J, Colombet M, Soerjomataram I, Mathers C, Parkin DM, Piñeros M, et al. Estimating the global cancer incidence and mortality in 2018: GLOBOCAN sources and methods. Int J Cancer 2019;144:1941-53.

7. Jemal AF, Bray MM, Center J, Ferlay EW, Forman D. Global cancer statistics. CA Cancer J Clin 2011;61(2):69-90.

8. Bahadur B, PullaiahT, Krishnamurthy KV. Angiosperms: An overview. In: Bahadur B, Rajan MV, Sahijram L, Krishnamurthy KV, editors. Plant Biology and Biotechnology. 1st ed. New Delhi, India: Springer; 2015;1:361-83. 
9. Tomlinson PB. Studies in systematic anatomy of the Zingiberaceae. Bot J Linn Soc 1956;55(361):547-92.

10. Singh CB, Manglembi N, Swapana N, Chanu SB. Ethnobotany, Phytochemistry and Pharmacology of Zingiber cassumunar Roxb. (Zingiberaceae). J Pharmacogn Phytochem 2015;4(1):16.

11. Jantan IB, Yassin MSM, Chin CB, Chen LL, Sim NL. Antifungal activity of the essential oils of nine Zingiberaceae species. Pharm Biol 2003;41(5):392-7.

12. Prabhu KM, Thomas VP, Sabu M. Economically important gingers. Proc Kerala Sci Cong 2010:22;816-7.

13. Kizhakkayil J, Bhas S. Diversity, characterization and utilization of ginger: A review. Plant Genet Resour 2011;9(3):464-77.

14. Nithya R, Jayshree N. A review on herbs of the zingiberaceae family with beneficial effects on cardiovasular diseases. World J Pharm Pharm Sci 2017;6(6):635-43.

15. Satish R, Dhananjayan R. Evaluation of anti-inflammatory potential of rhizome of Alpinia galangal Linn. Biomedicine 2003;23(1/2):91-96.

16. Matsuda H, Morikawa T, Managi H, Yoshikawa M. Antiallergic principles from Alpinia galanga: structural requirements of phenylpropanoids for inhibition of degranulation and release of TNF-alpha and IL-4 in RBL-2H3 cells. Bioorg Med Chem Lett 2003;13(19):3197-202.

17. Matsuda H, Pongpiriyadacha Y, Morikawa T, Ochi M, Yoshikawa M. Gastroprotective effects of phenylpropanoids from the rhizomes of Alpinia galanga in rats: structural requirements and mode of action. Eur $\mathrm{J}$ Pharmacol 2003;471(1):59-67.

18. Muangnoi U, Lee J, Thepouyporn A, Mirzayans R, Le XC, Weinfeld M, et al. Cytotoxicity, apoptosis and DNA induced by Alpinia galangal rhizome extract. Planta Med 2007;73(8):74854.

19. Singh JCH, Alagarsamy V, Diwan PV, Kumar S, Nisha JC, Reddy YN. Neuroprotective effect of Alpinia galanga (L.) fractions on $A \beta(25-35)$ induced amnesia in mice. $\mathrm{J}$ Ethnopharmacol 2011;138(1):85-91.

20. Roy B, Tandon V. Fluckicidal activity of Alpinia nigra (Zingiberaceae) against the trematode Fasciolopsis buski. Biomed Lett 1999;60:23-9.

21. Phongpaichit S, Vuddhakul V, Subhadhirasakul S, Wattanapiromsakul C. Evaluation of the Antimycobacterial Activity of Extracts from Plants Used as Self-Medication by AIDS Patients in Thailand. Pharm Biol 2005;44(1):71-5.

22. Le TB, Beaufay C, Nghiem DT, Mingeot-Leclercq MP, Quetin-Leclercq J. In Vitro Anti-Leishmanial Activity of Essential Oils Extracted from Vietnamese Plants. Molecules 2017;22(7):E1071.

23. Rastogi S, Pandey MM, Rawat AKS. Spices: Therapeutic Potential in Cardiovascular Health. Curr Pharm Des 2017;23(7):989-98.

24. Singh M, Hussain T, Firdous H, Shaikh S, Rizvi SMD, Moin A, et al. Preclinical Hepatoprotective Effect of Herbalism Against Ethanol Induced Hepatotoxicity: A Review. Curr Drug Metab 2018;19(12):1002-1011.

25. Srinivasan MR, Srinivasan KC. Cholesterol lowering activity of mango ginger (Curcuma amada Roxb.) in induced hypercholesterolemic rats. Eur Food Res Technol 2008;227(4):1159-63.

26. Policegoudra RS, Abiraj K, Channe Gowda D, Aradhya SM. Isolation and characterization of antioxidant and antibacterial compound from mango ginger [Curcuma amada Roxb.] rhizome. J Chromatogr B 2007;852(1-2):40-8.
27. Singh S, Kumar JK, Saikia D, Shanker K, Thakur JP, Negi AS, et al. A bioactive labdane diterpenoid from Curcuma amada and its semisynthetic analogues as antitubercular agents. Eur J Med Chem 2010;45(9):4379-82.

28. Ammon HPT, Wahl MA. Pharmacology of Curcumin longa. Planta Med 1991;57(1):1-7.

29. Singh G, Kapoor IPS, Singh P, de Heluani CS, de Lampasona MP, Catalan CAN. Comparative study of chemical composition and antioxidant activity of fresh and dry rhizomes of turmeric (Curcuma longa Linn.). Food Chem Toxicol 2010;48(4):102631.

30. Apisariyakul A, Vanittanakom N, Buddhasukh D. Antifungal activity of turmeric oil extracted from Curcuma longa (Zingiberaceae). J Ethnopharmacol 1995;49(3):163-9.

31. Jiang JL, Jin XL, Zhang $\mathrm{H}, \mathrm{Su} \mathrm{X,} \mathrm{Qiao} \mathrm{B,} \mathrm{Yuan} \mathrm{YJ.}$ Identification of antitumor constituents in curcuminoids from Curcuma longa L. based on the composition-activity relationship. J Pharm Biomed Anal 2012;70:664-70.

32. Yu ZF, Kong LD, Chen Y. Antidepressant activity of aqueous extracts of Curcuma longa in mice. J Ethnopharmacol 2002;83(1-2):161-5.

33. Kim HJ, Yoo HS, Kim JC, Park CS, Choi MS, Kim M, et al. Antiviral effect of Curcuma long a Linn. extract against hepatitis B virus replication. J Ethnopharmacol 2009;124(2):189-96.

34. Yoshioka T, Fujii E, Endo M, Wada K, Tokunage Y, Shiba N, et al. Antiinflammatory potency of dehydrocurdione, a zedoaryderived sesquiterpene. Inflamm Res 1998;47(12):476-81.

35. Syu WJ, Shen CC, Don MJ, Ou JC, Lee GH, Sun CM. Cytotoxicity of curcuminoids and some novel compounds from Curcuma zedoaria. J Nat Prod 1998;61(12):1531-34.

36. Chen W, Lu Y, Gao M, Wu J, Wang A, Shi R. Anti-angiogenesis effect of essential oil from Curcuma zedoaria in vitro and in vivo. J Ethnopharmacol 2011;133(1):220-6.

37. Othman R, Ibrahim H, Mohd MA, Mustafa MR, Awang K. Bioassay-guided isolation of a vasorelaxant active compound from Kaempferia galanga L. Phytomedicine 2006;13(1-2):616.

38. Kim NJ, Byun SG, Cho JE, Chung K, Ahn YJ. Larvicidal activity of Kaempferia galanga rhizome phenylpropanoids towards three mosquito species. Pest Manag Sci 2008;64(8):857-62.

39. Nugroho B.W, Schwarz B, Wray V, Proksch P. Insecticidal constituents from rhizomes of Zingiber cassumunar and Kaempferia rotunda. Phytochemistry 1996;41(1):129-32.

40. Stoilova I, Krastanov AI, Stoyanova A, Denev P. Antioxidant activity of a ginger extract (Zingiber officinale). Food Chem 2007;102(3):764-70.

41. Attari EV, Mahdavi MA, Javadivala Z, Mahluji S, Vahed ZS, Ostadrahimi A. A systematic review of the anti-obesity and weight lowering effect of ginger (Zingiber officinale Roscoe) and its mechanisms of action. Phytother Res 2018;32(4):57785.

42. Zheng J, Zhou Y, Li Y, Xu DP, Li S, Li HB. Spices for Prevention and Treatment of Cancers. Nutrients 2016;8(8):E495.

43. Lindblad AJ, Koppula S. Ginger for nausea and vomiting of pregnancy. Can Fam Phys 2016;62(2):145.

44. Singh CB, Singh LW, Lokendrajit N, Swapana N,Singh SB, Nongalleima KH. Biological and chemical properties of Zingiber zerumbet Smith. Phytochem Rev 2012;11(1):113-25.

45. Iqbal J, Abbasi BA, Mahmood T, Kanwal S, Sayed BA, Shah A et al. Plant-derived anticancer agents: A green anticancer approach. Asian Pac J Trop Biomed 2017;7(12):1129-50.

46. Asher GN, Spelman K. Clinical utility of curcumin extract. Alt 
Ther Health Med 2013;19:20-2.

47. Ryan JL, Heckler CE, Ling M, Katz A, Williams JP, Pentland $\mathrm{AP}$, et al. Curcumin for radiation dermatitis: a randomized, double-blind, placebo-controlled clinical trial of thirty breast cancer patients. Radiat Res 2013;180(1):34-43.

48. Zeng Q, Lu CL, Zhang X, Jiang JG. Isolation and identification of ingredients inducing cancer cell death from the seeds of Alpinia galangal, a Chinese spice. Food Funct 2015;6(2):43143.

49. Lu YH, Wang ZLT, Wei D, Xiang H. Mechanism and inhibitory effect of galangin and its flavonoid mixture from Alpinia officinarum on mushroom tyrosinase and B16 murine melanoma cells. J Enzyme Inhib Med Chem 2006;22(4):433-8.

50. Lee E, Park KK, Lee JM, Chun KS, Kang JY, Lee SS, et al. Suppression of mouse skin tumor promotion and induction of apoptosis in HL-60 cells by Alpinia oxyphylla Miquel (Zingiberaceae). Carcinogenesis 1998;19(8):1377-81.

51. Zhang Q, Cui C, Chen CQ, Hu XL, Li YH, Fan YH, et al. Antiproliferative and pro-apoptotic activities of Alpinia oxyphylla on HepG2 cells through ROS-mediated signaling pathway. J Ethnopharmacol 2015;169:99-108.

52. Hui F, Qin X, Zhang Q, Li R, Liu M, Ren T, et al. Alpinia oxyphylla oil induces apoptosis of hepatocellular carcinoma cells via PI3K/Akt pathway in vitro and in vivo. Biomed Pharmacother 2019;109:2365-74.

53. Li N, Zhang Q, Jia Z, Yang X, Zhang H, Luo H. Volatile oil from Alpinia officinarum promotes lung cancer regression in vitro and in vivo. Food Funct 2018;9(9):4998-5006.

54. Hsu CL, Yu YS, Yen GC, Anticancer effects of Alpinia pricei Hayata roots. J Agric Food Chem 2010;58(4):2201-8.

55. Faugeras AC, Bayet-Robert M, Bay J, Chollet P, Barthomeuf C. Possible Benefits of Curcumin Regimen in Combination With Taxane Chemotherapy for Hormone-Refractory Prostate Cancer Treatment. Nutr Cancer 2010;62(2):148-53.

56. Sharma RA, Euden SA, Platton SL, Cooke DN, Shafayat A, Hewitt HR, et al. Phase I Clinical Trial of Oral Curcumin: biomarkers of systemic activity and compliance. Clin Cancer Res 2004;10(20):6847-54.

57. Lakshmi S, Padmaja LG, Remani P. Antitumour Effects of Isocurcumenol Isolated from Curcuma zedoaria Rhizomes on Human and Murine Cancer Cells. Int J Med Chem 2011;2011:253962.

58. Lobo R, Prabhu KS, Shirwaikar A, Shirwaikar A. Curcuma zedoaria Rosc. (white turmeric): a review of its chemical, pharmacological and ethnomedicinal properties. J Pharm Pharmacol 2009;61(1):13-21.

59. Sivaprabha J, Dharani B, Padma PR, Sumathi. S. Induction of DNA damage by the leaves and rhizomes of Curcuma amada Roxb in breast cancer cell lines. J Acute Dis 2015;4(1):12-17.

60. Wang J, Li XM, Bai Z, Chi BX, Wei Y, Chen X. Curcumol induces cell cycle arrest in colon cancer cells via reactive oxygen species and Akt/ GSK3 $\beta /$ cyclin D1 pathway. J Ethnopharmacol 2018;210:1-9.

61. Zhou JL, Zheng JY, Cheng XQ, Xin GZ, Wang SL, Xie T. Chemical markers' knockout coupled with UHPLC-HRMSbased metabolomics reveals anti-cancer integration effects of the curcuminoids of turmeric (Curcuma longa L.) on lung cancer cell line. J Pharm Biomed Anal 2019;175:112738.

62. Rivera M, Ramos Y, Rodríguez-Valentín M, López-Acevedo $\mathrm{S}$, Cubano LA, Zou J et al. Targeting multiple pro-apoptotic signalling pathways with curcumin in prostate cancer cells. PLoS One 2017;12(6):e0179587.
63. Lelli D, Pedone C, Sahebkar A. Curcumin and treatment of melanoma: The potential role of microRNAs. Biomed Pharmacother 2017;88:832-4.

64. Lee Y. Cytotoxicity Evaluation of Essential Oil and its Component from Zingiber officinale Roscoe. Toxicol Res 2016;32(3):225-30.

65. Park GH, Park JH, Song HM, Eo HJ, Kim MK, Lee JW, et al. Anti-cancer activity of Ginger (Zingiber officinale) leaf through the expression of activating transcription factor 3 in human colorectal cancer cells. BMC Complement Altern Med 2014;14:408.

66. Bernard MM, McConnery JR, Hoskin DW. [10]-Gingerol, a major phenolic constituent of ginger root, induces cell cycle arrest and apoptosis in triple-negative breast cancer cells. Exp Mol Pathol 2017;102(2):370-6.

67. Yan H, Ren MY, Wang ZX, Feng SJ, Li S, Cheng Y, et al. Zerumbone inhibits melanoma cell proliferation and migration by altering mitochondrial functions. Oncol Lett 2017;13(4):2397-402.

68. Krajarng A, Chulasiri M, Watanapokasin R. Etlingera elatior Extract promotes cell death in B16 melanoma cells via down-regulation of ERK and Akt signaling pathways. BMC Complement Altern Med 2017;17(1):415.

69. Srivastava S, Ankita M, Kumar D, Srivastava A, Sood A, Rawat A. Reversed-phase high performance liquid chromatographyultraviolet photodiode array detector validated simultaneous quantification of six bioactive phenolic acids in Roscoea purpurea tubers and their In vitro cytotoxic potential against various cell lines. Phcog Mag 2015;11(44 Suppl 3):488-95.

70. Paramee S, Sookhee S, Sakonwasun C, Takuathung MN, Mungkornaswakul P, Minlamool W, et al. Anti-cancer effects of Kaempferia parviflora on ovarian cancer SKOV3 cells. BMC Complement Altern Med 2018;18(1):178.

71. Sohn JH, Han KL, Lee SH, Hwang JK. Protective effects of panduratin A against oxidative damage of tertbutylhydroperoxide in human HepG2 cells. Biol Pharm Bull 2005;28(6):1083-1086.

72. Kirana C, Jones GP, Record IR, Mcintosh GH. Anticancer properties of panduratin A isolated from Boesenbergia pandurata (Zingiberaceae). J Nat Med 2007;61(2):131-7.

73. Nurgali K, Jagoe RT, Abalo R. Editorial: Adverse Effects of Cancer Chemotherapy: Anything New to Improve Tolerance and Reduce Sequelae? Front Pharmacol 2018;9:245.

74. Cervello M, McCubrey JA, Cusimano A, Lampiasi N, Azzolina A, Montalto G. Targeted therapy for hepatocellular carcinoma: novel agents on the horizon. Oncotarget 2012;3(3):236-60.

75. Zhan HX, Xu JW, Wu D, Wu ZY, Wang L, Hu SY, et al. Neoadjuvant therapy in pancreatic cancer: a systematic review and meta-analysis of prospective studies. Cancer Med 2017;6(6):1201-19.

76. Morrison AH, Byrne KT, Vonderheide RH. Immunotherapy and prevention of pancreatic cancer. Trends Cancer 2018;4(6):41828.

77. Berretta M, Della Pepa C, Tralongo P, Fulvi A, Martelollotta F, Lleshi, et al. Use of complementary and alternative medicine in cancer patients : An Italian multicentre. Oncotarget 2017;8(15):24401-14.

78. Sakhanokho HF, Rajasekaran K. Hedychium Essential Oils: Composition and Uses. In: Malik S, editor. Essential Oil Research: Trends in Biosynthesis, Analytics, Industrial Applications and Biotechnological Production. 1st ed. Switzerland: Springer International Publishing; 2019;49-60.

79. Sirirugsa P, Larsen K. The genus Hedychium 
(Zinigiberaceae) in Thailand. Nord J Bot 1995;15:301-304.

80. Sanoj E, Sabu M, Kumar TR. Hedychium forrestii (Zingiberaceae) with a new synonymy and a variety from India. J Bot Res 2010;4(2):633-9.

81. Tanaka N, Ohi-Toma T, Aung MM, Murata J. Systematic notes on the genus Hedychium (Zingiberaceae) in Myanmar. Botany 2016;42(2):57-66.

82. Sakhanokho HF, Sampson BJ, Tabanca N, Wedge DE, Demirci B, Baser KHC, et al. Chemical Composition, Antifungal and Insecticidal Activities of Hedychium Essential Oils. Molecules 2013;18(4):4308-27.

83. Sarangthem N, Talukdar NC, Thongam B. Collection and evaluation of Hedychium species of Manipur, Northeast India. Genet Resour Crop Evol 2013;60(1):13-21.

84. Manish M. Current status of endangered medicinal plant Hedychium coronarium and causes of population decline in the natural forests of Anuppur and Dindori districts of Madhya Pradesh, India. Int Res J Bio Sci 2013;2(3):1-6.

85. Ribeiro RA, Barros F, Melo MMRF, Muniz C, Chieira S, Wanderely MDG, et al. Acute diuretic effects in conscious rats produced by some medicinal plants used in the state of Sao Paulo, Brasil. J Ethnopharmacol 1988;24(1):19-29.

86. Braga FC, Wagner H, Lombardi JA, Oliveira AB. Screening Brazilian plant species for in vitro inhibition of 5-lipoxygenase. Phytomedicine 2000;6(6):447-52.

87. Shrotriya S, Ali MS, Saha A, Bachar SC, Islam MS. Antiinflammatory and analgesic effects of Hedychium coronarium Koen. Pak J Pharm Sci 2007;20(1):47-51.

88. Valadeau C, Pabon A, Deharo E, Alban-Castillo J, Estevez Y, Lores FA. Medicinal plants from the Yanesha (Peru): Evaluation of the leishmanicidal and antimalarial activity of selected extracts. J Ethnopharmacol 2009;123(3):413-422.

89. Tse LS, Liao PL, Tsai CH, Li CH, Liao JW, Kang JJ, et al. Glycemia Lowering Effect of an Aqueous Extract of Hedychium coronarium Leaves in Diabetic Rodent Models. Nutrients 2019;11(3):629.

90. Suresh G, Reddy PP, Babu KS, Shaik TB, Kalivendi SV. Two new cytotoxic labdane-diterpenes from the rhizomes of Hedychium coronarium. Bioorg Med Chem Lett 2010;20(24):7544-8.

91. Zhan ZJ, Wen YT, Ren FY, Rao GW, Shan WG, Li CP. Diterpenoids and a diarylheptanoid from Hedychium coronarium with significant anti-angiogenic and cytotoxic activities. Chem Biodivers 2012;9(12):2754-60.

92. Ghosh S, Karin M. Missing pieces in the NF-kB puzzle. Cell 2002;109(2 Suppl 1):81-96.

93. Kang SS, Cuendet M, Endringer DC, Croy VL, Pezzuto JM, Lipton MA. Synthesis and biological evaluation of a library of resveratrol analogues as inhibitors of COX-1, COX-2 and NFkappaB. Bioorg Med Chem 2009;17(3):1044-54.

94. Chen JJ, Ting CW, Wu YC, Hwang TL, Cheng MJ, Sung PJ, et al. New Labdane-Type Diterpenoids and Anti-Inflammatory Constituents from Hedychium coronarium. Int J Mol Sci 2013;14(7):13063-77.

95. Giron N, Traves PG, Rodriguez B, Lopez-Fontal R, Bosca $\mathrm{L}$, Hortelano $\mathrm{S}$, et al. Suppression of inflammatory responses by labdane-type diterpenoids. Toxicol Appl Pharmacol 2008;228(2):179-89.

96. Chen JC, Hsieh MC, Lin SH, Lin CC, Hsi YT, Lo YS, et al. Coronarin $\mathrm{D}$ induces reactive oxygen species-mediated cell death in human nasopharyngeal cancer cells through inhibition of p38 MAPK and activation of JNK. Oncotarget 2017;8(64):108006-19.
97. Panigrahy SK, Kumar A, Bhatt R. Antioxidant potentials of successive solvent extracts from the unexplored Hedhychium coronarium rhizome. J Food Sci Technol 2017;54(10):3297306.

98. Donipati P, Sreeramulu SH. In vitro Anticancer Activity of Hedychium coronarium Against Human Breast Cancer Cell Line MCF-7. Int J Adv Res 2015;3(10):1497-501.

99. Ray A, Jena S, Dash B, Sahoo A, Kar B, Patnaik J, et al. Hedychium coronarium extract arrests cell cycle progression, induces apoptosis, and impairs migration and invasion in $\mathrm{HeLa}$ cervical cancer cells. Cancer Manag Res 2019;11:483-500.

100. Samant SS, Dhar U. Diversity, endemism and economic potential of wild edible plants of Indian Himalaya. Int J Sustain Dev World Ecol 1997;4:179-91.

101. Sravani T, Paarakh MP. Hedychium spicatum Buch. Ham.-An overview. Pharmacol Online 2011;2:633-42.

102. Giri D, Tamta S, Pandey A. A review account on medicinal value of Hedychium spicatum Buch-Ham ex Sm: Vulnerable medicinal plant. J Med Plants Res 2010;4:2773-7.

103. Tandon SK, Chandra S, Gupta S, Lal J. Analgesic and antiinflammatory effects of Hedychium spicatum. Indian J Pharm Sci 1997;59:148-50.

104. Balami NP. Ethnomedicinal uses of plants among the Newar community of Pharping village of Kathmandu district, Nepal Tribhuvan Univ J 2004;24:13-9.

105. Lamichhane J, Chhetri SB, Bhandari M, Pokhrel S, Timilsina R, Shrestha TM. Antiproliferative bioassay of extremophilic medicinal plants from Langtang Himalayan range of Nepal. J Biomol Reconstruct 2012;9(2):180-185.

106. Reddy PP, Rao RR, Shashidhar J, Sastry BS, Rao JM, Babu KS. Phytochemical investigation of labdane diterpenes from the rhizomes of Hedychium spicatum and their cytotoxic activity. Bioorg Med Chem Lett 2009;19(21):6078-81.

107. Bhatt ID, Prasad K, Rawat S, Rawal RS. Evaluation of antioxidant phytochemical diversity in Hedychium spicatum: A high value medicinal plant of Himalaya. Phog Mag 2008;4(16):202-205.

108. Sun Y. Free Radicals, antioxidant enzymes and carcinogenesis. Free Radic Biol Med 1990;8(6):583-7.

109. Biodiversity data of $H$. thyrsiforme. Available from: https:// www.gbif.org/occurrence/map?taxon_key=2758761

110. Jasril LYM, Ali AM, Sukari MA, Rahman AA, Othman AG, Kikuzaki $\mathrm{H}$, et al. Antioxidant and Antitumor Promoting Activities of the Flavonoids from Hedychium thyrsiforme. Pharm Biol 2003;41(7):506-511.

111. Pietta PG. Flavonoids as antioxidants. J Nat Prod 2000;63(7):1035-42.

112. Middleton Jr. E, Kandaswami C, Theoharides T. The effects of plant flavonoids on mammalian cells: Implications for inflammation, heart disease, and anticancer. Pharmacol Rev 2000;52:673-751.

113. Biodiversity data of $H$. ellipticum. Available from: https:// www.gbif.org/species/2758757.

114. Kumar S, Ziereis K, Wiegrebe W, Müller K. Medicinal plants from Nepal: evaluation as inhibitors of leukotriene biosynthesis. J Ethnopharmacol 2000;70(3):191-5.

115. Songsri S, Nuntawong N. Cytotoxic labdane diterpenes from Hedychium ellipticum Buch.-Ham. Ex. Sm. Molecules 2016;21(6):749.

116. Thanh BV, Dai DN, Thang TD, Binh NQ, Anh LDN, Ogunwande IA. Composition of essential oils of four Hedychium species from Vietnam. Chem Cent J 2014;8:54.

117. Lee J, Ha SJ, Park J, Kim YH, Lee NH, Kim YE, et al. 
1,8-cineole prevents UVB-induced skin carcinogenesis by targeting the aryl hydrocarbon receptor. Oncotarget 2017;8(62):105995-6008.

118. Kusuhara M, Urakami K, Masuda Y, Zangiacomi V, Ishii H, Tai S, et al. Fragrant environment with $\alpha$-pinene decreases tumor growth in mice. Biomed Res 2012;33(1):57-61.

119. Ryanchenko B, Tulupova E, Schmidt E, Wlcek K, Buchbauer $\mathrm{G}$, Jirovetz L. Investigation of anticancer and antiviral properties of selected aroma samples. Nat Prod Commun 2008;3:1085-8.

120. Liu YT, Hsieh MJ, Lin JT, Chen G, Lin CC, Lo YS, et al. Coronarin $\mathrm{D}$ induces human oral cancer cell apoptosis though upregulate JNK1/2 signaling pathway. Environ Toxicol 2019;34(4);513-20.

121. Ma Y, Wu Z, Tian X, Zhang C, Sun W. Growth discrepancy between filament and style facilitates autonomous selffertilization in Hedychium yunnanense (Zingiberaceae). Plant Ecol Evol 2012;145(2):b185-9.

122. Qing Z, Xio-qiong HE, Xiao-Jiang HAO, Cheng ZOU. Anticancer effect of diterpenes from Hedychium yunnanense. Nat Prod Res Devel 2010;22(3):395-7.
123. Li YP, Zhao SM, Xu JJ, Zeng GZ, Li Y, Tan NH, et al. New Labdane diterpenes from Hedychium yunnanense with cytotoxicity and inhibitory effects on nitric oxide production. Nat Prod Res 2016;30(23):2669-74.

124. Zhao Q, Qing C, Hao XJ, Han J, Zuo GY, Zou C, et al. Cytotoxicity of labdane-type diterpenoids from Hedychium forrestii. Chem Pharm Bull 2008;56(2):210-2.

125. Medeiros JR, Campos LB, Mendonça SC, Davin LB, Lewis NG. Composition and antimicrobial activity of the essential oils from invasive species of the Azores, Hedychium gardnerianum and Pittosporum undulatum. Phytochemistry 2003;64(2):5615.

126. Arruda M, Viana H, Rainha N, Neng NR, Rosa JS, Nogueira JMF, et al. Anti-acetylcholinesterase and Antioxidant Activity of Essential Oils from Hedychium gardnerianum Sheppard ex Ker-Gawl. Molecules 2012;17(3)3082-92.

127. Kumrit I, Suksamrarn A, Meepawpan P, Songsri S, Nuntawong N. Labdane-Type Diterpenes from Hedychium gardnerianum with potent cytotoxicity against human small cell lung cancer cells. Phytother Res 2010;24(7):1009-13. 